\title{
Management problems in the context of conceptual transformation of human capital
}

\author{
VALENTINE N. VANDYSHEV ${ }^{1}$ \\ Helena S. Perelomova ${ }^{2}$ \\ SUMY Sumy National Agrarian University, Ukraine, Department of Philosophy
}

\begin{abstract}
The article discusses the features of the transformation of the concept of human capital in the context of modern ideas about the development of socio-economic relations. The attention is paid to significant changes in the nature of human capital, which are influenced its further intellectualization and creativity. It also analyses the problems of human capital from the position of further perspective of alienation overcoming what at one time wrote Marx. It analyses the social ideas of Toffler in the context of opposition of three waves of civilization in modern Ukraine. Results of the study of the essence of human capital give reason to believe: the role of managing the process of its development is important.
\end{abstract}

Paper type: conceptual article

Keywords: alienation, cognitariat, consumetariat, human capital, intellect, leadership, management

\section{Introduction}

Modern global world of information has become very difficult due to the colossal growth of production, means of communication and opportunities for consumption of growing mass of goods and services. Obviously, the world will continue to become even more difficult.

\footnotetext{
1 alburnus.v@gmail.com

2 helena.perelomova@gmail.com
} 
The task of scientists and politicians - intellectually understand and comprehend what is happening in the world, thoroughly analyse the nature of the changes and respond to them on time. Such efforts and evaluation of economic and political changes have occurred repeatedly in history. Wherein scientific predictions had different levels of reasonableness and were perceiving differently by society. This can be explained in particular by speed and scale of change. A number of American and Western European scientists responded properly to changes that occurred in the Western world in the 1960s-1970s, as a result emerged and got a rapid development the socio-futurological concepts and models of human development. Scientific pluralism contributed to the identification of different versions of the future society "post-capitalist" by Dahrendorf (1975), "post-industrial” by Bell (1973), "post-civilizational” by Boulding (1978), "new industrial” by Galbraith (1967), "industrial in a phase of maturity" by Aron (1967), "advanced industrial" by Marcuse (1967), "super-industrial” by Toffler (1980), "technotronic" by Brzezinsky (1970), and so on. The authors of these concepts were guided by the common methodological orientations, considering that the reindustrialization is necessary, that is such industrialization, in which science and technology will be the humanist and will not destroy the natural in man and the environment. Moreover, they believed that science and technology in the new conditions will promote universal human values and will secure mankind on planet Earth.

Enough thoroughly and carefully Western scholars and politicians approached to the evaluation of role and importance of human capital - the essential component of spiritual and economic development of society. The author of the concept of human capital (1961) is considered Schultz, whose ideas in terms of economics further developed Becker. To the nature and prospects of development of human capital studies at different times turned Kuznets, Denison and others (Becker, 1964, 1994; Flamholtz, 1985; Mann, 1965; Schultz, 1971).

Note that in addition to research prospects of socio-economic development and human capital development issues also the attention was paid to the problems of production, management and leadership. It is the search for innovations in technology and technology for industrial production, the rapid development of information and communication tools, introducing a variety of support services and transport services that have intensified the need for a new type of managers - managers with leadership qualities. Among the successful researches of the problem of management and leadership we can specify works of Mintzberg (2010), Siebens (2007), Covey (1999), Schein (1992), Snyder (Snyder, Dowd, \& Houghton, 1994), Willner (1984), Kohut (1991), and other.

According to the authors, the problem of human capital management in the context of its development, and especially the problem of forming leadership skills, given the challenges which today arose to the international community, requires further thorough scientific analysis. 
Thus, the purpose of this study is a synthesis of ideas about human capital in historical and philosophical perspective and to define those components of human capital that could be perspective for the formation of the personality of the leader.

The study used an analytical method which allowed to isolate the main problems in the development and management of human capital. The use of comparative-historical method made it possible to trace the origins and formation of the concept of human capital in the context of ideological stereotypes and values that define features of its perception in modern society compared to current ideas.

\section{The concept of "work," "labour force" and "human capital"}

The concept of "human capital" has its own history, although it hasn't been always determined exactly in this way. Human capital is a universal concept, which covers a set of specific human properties that are required to perform a social role. Undoubtedly, these properties do not appear out of nowhere. They appear as a result of a number of factors, but primarily as the development of appropriate individual inclinations in the formation and education of his personality.

At the time, working on philosophical and economic works of prominent thinkers of the $17^{\text {th }}$ and $19^{\text {th }}$ centuries, Marx and Engels wrote about the importance of human labour, that we can see in their works of 1840s-1850s. In 1844, Marx (1974, pp. 113-114) stressed that labour is graded, split and therefore not free, it is the source of the disastrous of private property and alienated from human existence. Here he notes that Fourier and Saint-Simon differently defined their priorities about the meaning of work. If Fourier favoured agricultural labour on earth, then Saint-Simon wrote about the benefits of industrial work which improves the living conditions of workers. Engels also applied the concept of work when he wrote that the increase of the proletariat amount, the class society, "which lives solely by their work," (1974, p. 355) due to the division of labour, enriched capitalists. Also in this period, the founders of Marxism widely used the concept of "cost of labour," "labour price," "labour sale." But since the late 1850s, when Marx began to develop the theory of surplus value, he determined that the worker sells to the capitalist not his work but his labour force. Therefore, in his subsequent writings, Marx and Engels began to use the term "labour costs," "price of labour," "sale of labour."

Obviously, the concept of labour is significantly different from the concept of work, especially if we consider their meaning in the context of capitalist relations. Marx focused Owen's thought that "since the general introduction of non-living mechanisms in the British manufacturing the people, with few exceptions are regarded as a secondary and less important machine, and much more attention is paid to the improvement of raw materials - wood and metal than to the improvement of body and spirit" (Marx, 1980b, p. 223). From this judgment Marx makes 
a perspective conclusion, that economy of work time is identical to the increase of leisure time that promotes the full development of the individual. "In terms of the direct production process, saving of time can be regarded as the production of the main capital, and what is more this main capital is the man itself" (Marx, 1980b, p. 223). However, the free time puts a person to a choice: whether to use it as an entertainment or as an opportunity for a more sublime activity for the development of its human capital. For a man who is being formed the production process is a school of discipline, said Marx and speaking about a man who has already learned the knowledge accumulated by society, "it is an application of (knowledge), experimental science, materially creative and substantively embodied science" (Marx, 1980b, p. 224).

However, as proves the development of capitalism, the value of man as the bearer of human labour generally was limited by all sorts of obstacles on the way of getting first of all a comprehensive education. That is why Engels said: “(...) we see that the development of the proletariat in nearly all countries is violently suppressed by the propertied classes" (1974, p. 358). Marx also emphasized that “(...) capitalism, which tends to increase immensely productive forces, however, makes it one-sided, limits, etc. the main productive force which is the man himself" (1980a, p. 407). Thus, referring to the works of Marx and Engels allows us to clearly see that they define the human not only as the capital's component but also as the main productive force. And therefore the contribution to the full development of the individual is the contribution to the development of human capital. Thus, the overall human capital, like any other capital is a person's ability to make a profit.

In the new historical conditions, as we have noted above, deepening of the essence of the concept of human capital was further developed. Milken (b. 1946) American financier and philanthropist used this concept, summarizing the business innovations of the Italian entrepreneur Merloni. Merloni - founder of the famous company manufacturing electrical home appliances Indesit on the verge of 1980s1990s implemented an effective system of parts usage for production and finished products, minimizing its number in the stocks. Using computers and highly intellectual technologies in the production and in the accelerating the delivery of goods to the consumer, he has achieved significant savings in resources, which gave him a reason to believe that intellectual capital replaces expensive equipment. In this way, human capital has replaced money capital. Here we see attempts to emphasize innovation and intellectual components of human capital. Toffler and Toffler (1995, p. 55) in the book Creating a new civilization. Politics of the Third Wave also noted that knowledge reduces the need for raw materials, labour, time, space and other resources, becoming the main resource of the modern economy. Moreover, the "proletariat" is more and more replaced by "cognitariat" and so now it is in the minority. 


\section{The essence of human capital}

At the heart of the human capital of income generation are innate human abilities (what philosophers call its essence), education and acquired competences. Today it is clear that not only modern production, but computerized information service sector needs more intellectually trained workers. Thus, high-tech manager is a new profession that is needed in the tourism sector, hotel business, supermarket and more. In turn, Bard and Söderqvist (2004, p. 9) pay attention to the significant changes taking place in consumption sphere, and introduced the concept of "consumetariat," defining thus the emergence of the new lower consumer class, which replaces proletariat in the new society. Here we see a contradiction, but it can be explained, given that consumetariat is a class that opposite to netocracy - dominating class, according to Bard and Söderqvist.

Reflecting on the essence of human capital, we must admit that initially a person must be educated and formed in accordance with a purpose. This purpose is determined by parents, close environment, social environment, and in some kind global world trends. It is therefore important that education of fully developed personality allows it to adapt easily enough either for own selected professional activity or for the circumstances of surrounding social life that have a strong tendency to change.

The main factors that on the minimal level determine human capital can be considered health, physical strength, professional knowledge and intellectual abilities. From a historical perspective physical strength of personality played a crucial role of human as productive forces in the early stages of human development. Based on the teachings of Marx, this phase coincides with the slave and feudal structure of society. And judging from the basic ideas of the concept of Toffler, this time of The First Wave - agricultural stage of social development. There is a fairly clear distinction of social status, as well as a community of people who generate ideas, but does not seek their material embodiment. On this occasion, Plekhanov wrote (1956, p. 615): "Plutarch, referring to the inventions made by Archimedes during the siege of Syracuse by the Romans, considers it necessary to forgive inventor, philosopher certainly ought not to engage in this kind of things, he muses, but Archimedes is justified by the extremeness, in which was located his homeland." It is interesting, that a number of gauges and instruments in the period of formation of classical mechanics called philosophical instruments (accurate scales, thermometers, theodolites, telescopes, microscopes, etc.) (Marx, 1975, p. 477).

At the stage of social development that meets capitalism, human capital is not limited to physical force because some of the workers should have the necessary professional knowledge to manage the machine. Actually, the machine itself is a part of human capital in the form of physical strength spent on its production and in the form of intellectual efforts (the idea, scheme, draft). It made a man an ap- 
pendage of machine and paid very few attentions to "the improvement of body and spirit." More and more there was a division of labour into intellectual and physical, so proletariat was doomed to toil beside machine. This gave reason to Karl Marx argued (1974, p. 53) that proletariat is a man who "lives only in his one-sided, abstract labour." Hence we speak of alienation as an essential feature of capitalism. Since the overcoming alienation begins, according to Marx, the first stage or the first form of communism.

Note that it is the first form of communism, which was later apparently was defined as post-industrial information society or The Third Wave, and became the object of meticulous study of a number of philosophers and economists of 1960s1970s. Marx wrote that communism of the first form “(...) a dual kind: first, the domination of the real property on it is so great that he wants to destroy everything that, everybody in principle of private property cannot own all; he wants to force aside from talent. Direct physical ownership seems to it as the only purpose of life and existence; category of worker is not abolished but extended to all men; the ratio of private property is the attitude of the whole society to the world of things" (Marx, 1974, p. 114). Despite these limitations, this communism has "imagine himself as reintegration or return of man to himself as the destruction of human self-alienation" - said Marx (1974, p. 116).

Is this communism was held in its first form? Apparently so. Just look at the society of "universal welfare" in advanced capitalist countries already mentioned of the late 1950s - early 1970s. Mass production of wireless devices, TVs, washing machines, cars, etc., which could buy large segments of the population, engaging in the production and maintenance of masses of men and women (blue and white collar) - all this are the evidence of "rule of the material property." But we should not forget that it was accompanied by a drop in morale, destruction of family values, sexual revolution, millions hippie, revolutionary actions of French students and so on (Buchanan, 2004). By the way, the theme of leadership at this time was not particularly relevant, since the status of skilled workers was sufficient for a normal life.

Regarding leadership here is the opportunity to spend some historical parallels, referring, for example, observing "human capital" that Ford did in 1910-1920 years. He said (Ford, 2015, p. 134): "we can barely find more than five percent of those who works for hourly pay, who, in addition to the desire to get more money, may take on extra responsibility and the extra work that is essential attributes of a higher official position ... Thus, despite our big labour, the difficulty lies not in identifying people able to move forward, but people who want it." Actually, here is the explanation: in the relatively calm and stable period of development of society "the vast majority of people want to stay at their place. They want to be led" (Ford, 2015, p. 134). The actual topic of leadership became later, when there was the Great Depression.

Obviously, the ideas of Marx and the essence of his teachings throughout the $19^{\text {th }}$ and $20^{\text {th }}$ centuries became the subject of numerous studies of both the procom- 
munist and probourgeois scientists. A theory of communism was perhaps the most controversial of all his philosophical heritage. The experience of totalitarian states that "were building communism" is also revealing. Therefore, Marx $(1974$, p. 116) concluded that "communism as the positive abolition of private property - the alienation of man - and therefore..." the return of man to himself as a social person that is humane, till definite time could be seen as too speculative. No less speculative and therefore not entirely clear till definite time was the judgment that this communism is complete naturalism and humanism that "(...) it is a real solution to the contradiction between man and nature, man and man, the true solution to the contradiction between the existence and substance, between materialization and selfaffirmation, between freedom and necessity, between the individual and family" (Marx, 1974, p. 116).

Clearly, there is no such communism yet, but the fact that the movement in this direction exists proves that the current socio-economic situation is undergoing significant changes. So, based on their observations and research Toffler and Toffler (1996) say that today workers who find themselves in superconscious activities produce much more without coercion, and it follows that the performance of their work begins even before they come to the office. For a new generation of supersymbolic leaders, inclined to think faster in terms of systems rather than in terms of separate steps, it will be natural (Toffler \& Toffler, 1996). This assumption, in our opinion, quite productive because supersymbolic activity is the image of a modern society in contrast to the significant proportion of alienation inherent in industrial society.

Supersymbolic activity - an activity aimed at identifying of the product with the manufacturer, which is especially noticeable in highly intellectual program materials. This is a manifestation of the same "reintegration," which wrote Marx (1974, p. 116). In the new socio-economic conditions, the idea of human about his place and role in society changes.

In view of the above, the essence of human capital can be viewed in two ways. On the one hand - a combination of direct workers (proletariat and cognitariat), workers-consumers (consumetariat) and only consumers. On the other hand is lower levelled managers, mid-level and top-level managers, who organize the global system of production and consumption. Modern human capital is able to organize production, to develop and introduce new technologies, but it has not yet found the capacity to solve current pressing global social problems of mankind. This requires managers with a global outlook, true leaders who have appeared at critical moments in history.

Defining the specific three waves of the historical development of mankind, Toffler has shown that among the main forces representing the agricultural, industrial and postindustrial (information) waves, there is inevitable struggle. In fact, we see it in the last half century. 


\section{Human capital management}

Naturally, in relation to the management human capital has a specific functions and purposes. Their dimension in modern society depends on what level of management tasks need solution. Because of modern global information society requires many managers of local and global level with features that meet the spirit of the time.

The modern system of training and education of personnel for production and maintenance involves in this process many subjects. In particular, the following could be many professional schools, institutes, universities, business schools and more. Recruitment function for such particular purposes perform either directly an institution that requires employees or recruitment agencies, assessment-centers and similar institutions which on the basis of finding out the level of general education, level of professional knowledge, communication skills, through various kinds of tests, etc. concludes regarding the suitability of the applicant and recommend its customers training.

Undoubtedly, a measure of suitability for administrative activity is a practice that as a litmus paper detects managerial potential of manager. Human possibilities as a head are manifested in the process activity and cooperation in a particular group. In this sense, networking, as a creation of the most extensive network of useful contacts and relationships, given the largely subjective approach of its members to offer of candidates, is based on the limited motivation.

Human capital which requires the field of modern management - a special kind of product. After all, we are talking about professionals who have in one way or another to create or implement innovative product. To do this, they must have formed and to some extent the established worldview, based on recognition of and respect for human values. Thus, with the existing system of principles and attitudes, the manager must be prepared to defend them, applying his knowledge and effort.

Any management decision involves the definition of the attitude to the opposition man-thing, purpose-means. Things are made for people with the participation of the people. Therefore, the role which is determined for the producer and consumer, is derived from the philosophy and value system of manager.

The system of the formation of human capital for the management activity has a long tradition as a recognized need. However, there are obvious differences. In established democracies there are reputable schools, including Eton, Oxford, Cambridge (England), Harvard, Princeton, Stanford (USA) where specialists come with a high level of knowledge and state approach to management activities. In totalitarian regimes of Soviet-style training managers also received much attention, but the process was multistage. As a result, the system was receiving a staunch ideological leader dedicated to this system, which it educated.

The situation with human capital management has changed significantly in recent decades, due to the emergence of a number of post-colonial, post-Soviet 
and other modes. Some old school administrators either initiated by themselves or adapted to the situation of "privatization" of social wealth and mineral resources and actively involved in the process, abandoning the principles which the system have shaped in them. Young managers who have been involved in managerial training in the new system, or haven't such, have taken control, without proper public awareness of their role, except the desire to enrich themselves at the expense of society. All this has led to polarization of the property to the huge social tension and open armed confrontation that took and take many lives.

It was the leaders and managers of different levels of post-Soviet and post-colonial regimes, which can generally be called transitional regimes now demoralize the Western system of governance and shake its principles. On the foreign policy level, this is particularly evident in the last decade.

Perhaps the best way would be to consider this situation, given the complex configuration plexus of three waves of civilization, the essence of which has determined Alvin and Hide Toffler in their famous works. They said (Toffler \& Toffler, 1996): "In the world, which is divided into three parts, the sector of World First Wave supports agricultural and mineral resources, the sector of the Second Wave provides cheap labour and produce mass production, and rapidly growing sector of the Third Wave uses a new method of domination - the establishment and operation of knowledge."

Enough tells us the example of internal and external events that are happening in Ukraine. It is important that here coexist simultaneously all three sectors and the relevant community. Living in one place at the same time, but with very different worldviews and values, they objectively are at war with each other. Agro-commodity production and life; metallurgy and chemical industry, high-tech information sector, together with a large part of highly educated professionals in all three sectors, high levels of corruption and a striking disparity in the distribution of public goods - is world in miniature. It is the territory of Ukraine where the struggle of three civilizations is the most obvious.

One cannot mention the problems facing the education system today, as the basis of human capital formation. Marx and Engels repeatedly emphasized that big business is against the fact that workers receive adequate education, and therefore very few pay attention to "the improvement of the body and the spirit" of workers. Thus, the capital of that time tried to make a high-level education inaccessible to ordinary workers. The current capital is also against the spread and support of elite education, said Fukuyama (2016), stressing that the reasons for this are clear. But the main reason, according to him, is that the modern state bureaucracy in Germany, Britain, France, Japan modernize the higher education system in a way that does not benefit the state administration. Clearly, this limits the development of human capital of future senior executives, forming their outlook, life values and view of the world, aimed at the preservation and conservation of the existing system. 
This negative trend is contrary to the direction of modern production, which according to Toffler and Toffler (1996) should be regarded as a substantial process than it represented by economists and ideologists of "narrow-minded" economy because now namely knowledge, rather than cheap labour, and the symbols, not the raw materials are implemented into concrete form and increase the value of the product.

\section{Conclusions}

Thus, the experience of numerous studies of prospects modern society development once again proves that the historical tradition of critical periods in the history of intellectuals requires not only to put the first and the last questions, but also to give a response. Modern world came into motion in all directions, which had never happened before. Naturally, the large numbers of people are confused, do not understand where the world is moving. There is an erosion of values, to the relevance of which people stop believing.

The only creative and productive force that has always changed and will change the world - is the human capital. Therefore, people who are able to manage the community today should focus on the creation of a social order where each person was given the opportunity to perform their public function, productive use of their human capital.

Scientists who studied the main factors of occurrence and the main features of the new post-industrial world, did a great job, but still remains an urgent need for fundamental generalizations and innovative vision changes. At the same time, they study the realities of the modern world have allowed a deeper understanding of the ideas of Marx referring to the future world, which he called the first form of communism. Undoubtedly, Marx was deep and daring analyst. He understood that one cannot always be in the past, as the world is aimed to the future and creative scientific thought should outpace its movement.

The challenges faced by today's leaders are much more complex than those that were before, although intellectual and material resources to solve existing problems also increased significantly.

Today the future world has no clear structure of values; it exists as a disembodied wonderful idea. To fill it with meaning and values and to make an appropriate material force can managers who join the vibrations of spiritual principles and realize their potential, correlating their actions with a higher principle, of truth. Humility before the truth, understanding needs and the inevitability of change, responsibility and a keen sense of justice - these leader features will help them in the dissemination and implementation of their ideas, as it has happened in human history. 


\section{References}

Aron, R. (1967). The Industrial Society. Three Essays on Ideology and Development. London: Weidenfeld \& Nicolson.

Bard, A., \& Söderkvist, J. (2004). Netocracy. The New Ruling Elite and Life after Capitalism. St.Petersburg: Stockholm School of Economics in St.-Petersburg.

Becker, G.S. (1964). Human Capital. New York: Columbia University Press.

Becker, G.S. (1994). Human Capital: A Theoretical and Empirical Analysis. New York: Basic Books.

Bell, D. (1973). The Coming of P-industrial Society: A Venture of Social Forecasting. New York: Basic Books.

Boulding, K.E. (1978). Ecodynamics: A New Theory of Societal Evolution. Beverly Hills: Sage.

Brzezinsky, Z. (1970). Between Two Ages: America's Role in the Technetronic Era. New York: Viking Press.

Buchanan, P.J. (2004). Death of the West. Moscow: OOO Izdatelstvo AST.

Covey, S.R. (1999). Principle-Centred Leadership. London: Simon \& Schuster UK Ltd.

Dahrendorf, R. (1975). The Crisis of Democracy, Report on the Governability of Democracies to the Trilateral Commission. Excerpts of remarks by Ralf Dahrendorf on the governability study. New York: New York University Press.

Engels, F. (1974). The Project of the Communist Creed. In K. Marx \& F. Engels, Works. Vol. 42. Moscow: Politizdat.

Flamholtz, E.G. (1985). Human Resource Accounting. New York: Jossey-Bass Publ.

Ford, H. (2015). My life and Work. Kiev: Nash Format.

Fukuyama, F. (2016). What is Corruption? retrieved from: https://www.gov.uk/government/ publications/against-corruption-a-collection-of-essays/against-corruption-a-collectionof-essays [accessed: 12.05.2016].

Galbraith, J.K. (1967). The New Industrial State. Boston: Houghton Mifflin.

Global Strategies Insights from the World's Leading Thinkers (1994); with a Preface by Percy Barnevik; afterword by Rosabedth Moss Kanter. Boston, MA: Harvard Business Review Book.

James, W.D. (1998). Leadership Selection in Six Western Democracies. London [etc.]: Fitzroy Dearborn.

Kohut, T.A. (1991). Wilhelm II and the Germans. A Study in Leadership, New York [etc.]: Oxford University Press.

Mann, F.C. (1965). Toward an Understanding of the Leadership Role in Formal Organization. San-Francisco: Chandler.

Marcuse, H. (1967). Negations: Essays in Critical Theory. Boston: Beacon Press.

Marx, K. (1974). Economic and Philosophic Manuscripts of 1844. In K. Marx, F. Engels, Works. Vol. 42. Moscow: Politizdat.

Marx, K. (1975). Economic Manuscripts of 1861-1863. In K. Marx, F. Engels, Works. Vol. 47. Moscow: Politizdat.

Marx, K. (1980a). Economic Manuscripts of 1857-1861. Part 1. Moscow: Politizdat.

Marx, K. (1980b). Economic Manuscripts of 1857-1861. Part 2. Moscow: Politizdat.

Mintzberg, H. (2010). Leadership Insights. Boston, Mass: Harvard Business School Publishing.

Plekhanov, G.V. (1956). The Development of the Monist View of History. Selected Philosophical Works, Vol. 1. Moscow: Politizdat.

Schein, E.H. (1992). Organizational Culture and Leadership (2 ${ }^{\text {nd }}$ ed.). San Francisco: JosseyBass Publishers.

Schultz, T. (1971). Investment in Human Capital. New York: Jossey-Bass Publishers. 
Siebens, H. (2007). Facilitating Leadership. Antwerpen: Apeldoorn Garant.

Snyder, N.H., Dowd, J.J. Jr., \& Houghton, D.M. (1994). Vision, Values and Courage Leadership for Quality Management. New York: Free Press, Toronto: Maxwell Macmillan.

Toffler, A., \& Toffler, H. (1995). Creating a New Civilization. The Politics of the Third Wave. Atlanta: Turner Publishing, Inc.

Toffler, A., \& Toffler, H. (1996). Creating a New Civilization. The Politics of the Third Wave. Retrieved from: http://krotov.info/libr_min/19_t/of/ler_02.htm [accessed: 12.05.2016].

Toffler, E. (1980). The Third Wave. New York: Bantam Books.

Willner, A.R. (1984). The Spellbinders Charismatic Political Leadership. New Haven, Conn.: Yale University Press.

\section{Notes about the Authors}

Valentin N. Vandyshev - a professor, Head of the Department of Philosophy, Sumy National Agrarian University, SUMY, Ukraine. The scientific interests of the author include history of philosophy, philosophical anthropology, science in Poland in the $15^{\text {th }}-16^{\text {th }}$ centuries (Yuriy Drohobych, Nicolaus Copernicus), management and leadership, logic, rhetoric, religion, occultism, lingvophilosophy, literature, communication theory. More than 370 scientific and scientific-methodical works, of which more than 50 monographs and textbooks were published. More than 50 publications in Poland, Czech Republic and Germany. The translation and publication of works of Ukrainian-Polish philosopher, professor of the Jagiellonian University Yuriy Drohobych (1448-1494) was organized. The author participated in the work of more than 380 scientific conferences (more than 40 of them abroad). He personally organized and held 20 international conferences. Visiting professor at the University of Olsztyn, Warsaw University of Life Sciences. A member of the editorial boards of six scientific journals in Ukraine and six in Poland.

Helena S. Perelomova - a professor of the Department of Philosophy, Sumy National Agrarian University, SUMY, Ukraine. The scientific interests of the author include linguophilosophy, linguoculturology, cognitive science, theory of communication, rhetoric. The author of more than 150 scientific and scientific-methodical works, including the number of monographs and textbooks. Also was published scientific articles in Poland, Czech Republic, Slovakia, Germany, Hungary, Georgia (SCOPUS). The number of articles were translated and issued in Poland. Helena S. Perelomova is a participator of (more than 200) and co-organizer of the number of international scientific conferences. Visiting professor at Wyższa Szkoła Menedżerska in Warszawa. A member of the number of editorial boards of scientific journals in Ukraine and in Poland. 